\title{
Product fermentation and gas production in vitro of feed content from Moringa oleifera, Lamm and Paraserianthes falcataria leaves
}

\author{
E Marhaeniyanto ${ }^{1}$ and S. Susanti ${ }^{1}$ \\ 1) Faculty of Agriculture, Tribhuwana Tunggadewi University, Jl. Telaga Warna, Malang 65141, Indonesia
}

\begin{abstract}
This study aims to determine the best composition Moringa oleifera, Lam (MOL) and Paraserianthes falcataria (PFL) leaves supplementation in the feed to produce fermentation process and low $\mathrm{CH}_{4}$ gas production. Concentrate feed is composed of MOL, PFL, plus coconut cake (CM), and solid cassava waste $(O)$. The study was conducted with a factorial experiment, arranged in a randomized complete block design (RBD). The first factor is 4 types of concentrate: $A, B, C$ and $D$. The second factor is the proportion of concentrates $A$, $B, C, D$ and maize stover (Zea mays) (M). as follows: P1, P2 and P3. The usage of concentrate feed (MOL $30 \%$ : PFL 10\% : coconut cake $45 \%$ : solid cassava waste 15\%) with the proportion of concentrate $50 \%$ : forage $50 \%$ was be able to produce normal fermentation process with indicated DM degradation $66.4 \%$, OM degradation $70.41 \%$, gas production $94.8 \mathrm{ml}$, microbial biomass $46 \mathrm{mg}, \mathrm{pH} 6.67, \mathrm{NH}_{3}$ concentration 7.48 $8.29 \mathrm{mg} / 100 \mathrm{ml}$ rumen fluid and proportion $\mathrm{VFA}\left(\mathrm{C}_{2}: \mathrm{C}_{3}: \mathrm{C}_{4}=65: 26: 9\right)$ and the lowest $\mathrm{CH}_{4}$ gas production (< $1 \%$ 24-hour incubation). In the future studies are in-vivo testing of the usage of MOL $30 \%:$ PFL $10 \%$ in the concentrate feed.
\end{abstract}

Keywords: $\mathrm{CH}_{4}$, in vitro, leaf of moringa, supplementation

\section{Introduction}

Manipulation of rumen fermentation processes aimed at improving the productivity of ruminants. The result of the fermentation process in the rumen is volatile fatty acid (VFA), ammonia $\left(\mathrm{NH}_{3}\right)$, microbial protein and methane $\left(\mathrm{CH}_{4}\right)$ and $\mathrm{CO}_{2} . \mathrm{CH}_{4}$ production in the rumen of ruminant livestock in the tropics is relatively high due to the low quality feed. Feed low-quality low impact on livestock production and increased $\mathrm{CH} 4$ emissions. Total $\mathrm{CH}_{4}$ emission fermented feed on cattle, buffalo, sheep and goat estimated 72 million tons in 2004 and contributed to the pollution of $\mathrm{CH}_{4}$ in the atmosphere by $17-30 \%$ [1]. Efforts to control the production of $\mathrm{CH}_{4}$ with antibiotics, growth hormones and chemicals cause residue in the product as well as toxic effects on livestock, so it is not recommended for use [2].

Alternatives to suppress $\mathrm{CH}_{4}$ production has been carried out with the use of natural additives of some legume plants containing secondary compounds tannins and saponins. [3],[4],[5] and [6] reported on the presence of condensed tannins (CT) on several of forage crops was be able to protect protein from excessive degradation processes in the rumen, so that to increase the amount of protein that is readily absorbed in the small intestine. Other reports suggested that saponin compounds are toxic to bacteria and protozoa in the rumen [7],[8],[9],[10],[11]. Some methanogens symbiosis with protozoa. Which is it may act as a donor $\mathrm{H}_{2}$. Although the effect on methanogens do not always correlate with the effects on protozoa [12]. Inhibited the growth of protozoa, the availability of $\mathrm{H}_{2}$ from reduced protozoa, methanogens number attached to the protozoa will be reduced, thus decreasing the production of $\mathrm{CH}_{4}$.

Leaves of Moringa oleifera, Lam (MOL) has 26 kinds of antioxidants and amino acids essential to the ideal composition according to nutritional standards of FAO [13]. Benefits of adding MOL in lactating dairy cattle feed showed that the administration of as much as $25 \%$ in the molasses block (approximately $100 \mathrm{~g} /$ head / day) was able to increase the milk production of $4 \%$ FCM of $9.80 \mathrm{~kg} /$ head / day to $10.6 \mathrm{~kg} /$ head / day. The results of the study [14] proved that supplementation of urea molasses block-based MOL significant effect $(\mathrm{P}<0.05)$ to increase feed intake of DM by $18 \%$ and average daily gain of goats were very real to $100 \mathrm{~g} / \mathrm{head} /$ day $(\mathrm{P}<0.01)$. Approach through in-vitro studies, the addition of MOL was able to increase microbial protein synthesis significantly [15] that is thought to be a factor supporting the increase in milk production of dairy cows. Report [16] in goats also showed that the MOL replace cotton oilcake and produce weight gain $20 \%$ higher when compared with the control feed. However, the publication of MOL and PFL utilization for animal feed in Indonesia is still very limited. MOL and PFL selected because of the high protein content and low $\mathrm{CH}_{4}$ yield. This study aims to determine the best composition MOL and PFL supplementation in the feed concentrate to produce a fermentation process with low $\mathrm{CH}_{4}$ gas production. 


\section{Methodology}

The experiment was conducted at the Laboratory of Animal Nutrition and Feed, Faculty of Animal Husbandry, Brawijaya University. Leaves of tree foliage (MOL and PFL) collected from Malang areas were air forced dried in the oven at $60^{\circ} \mathrm{C}$ until the weight was constant. Milled material with a size of $1 \mathrm{~mm}$ for proximate [17] and fibre analysis [18]

Concentrate feed is composed of MOL, PFL, plus coconut cake (CM), and solid cassava waste / onggok (O). The study was conducted with a factorial experiment, consisting of 4 types of concentrate, 3 proportions of forage provision, arranged in a randomized complete block design (RBD). The first factor is 4 types of concentrate: A (MOL 0\%: PFL0\%; CM 85\% : O 15\%), B (MOL 10\%: PFL 10\%: CM 65\%:O 15\%), C (MOL 20\%: PFL 10\%: CM 55\%:O 15\% ) and D (MOL 30\%: PFL 10\%: CM 45\%: O 15\%). The second factor is the proportion of concentrates A, B, C, D and maize stover (Zea mays) (M) as follows: P1 (concentrates 30\%: M 70\%), P2 (concentrates 40\%: M60\%) and P3 (concentrates 50\%: M50\%). Each treatment combination was repeated 3 times. The variables measured were (1) nutrient compositions (2) gas production, (3) degradation of dry matter (dDM), degradation of organic matter (dOM), (4) microbial biomass, and (5) methane gas production.

The process of fermentation in vitro using techniques [19]. Rumen fluid taken in the morning before the fistulated dairy cows was fed. The fistulated dairy cows with body weight approximately $350 \mathrm{~kg}$ were fed maize stover $(7.93 \% \mathrm{CP}) 20-25 \mathrm{~kg} \mathrm{head}^{-1} \mathrm{day}^{-1}$ and commercial concentrate $(16 \% \mathrm{CP}) 5 \mathrm{~kg} \mathrm{head}^{-1} \mathrm{day}^{-1}$. Drinking water was always available ad libitum. After collecting, the rumen fluid filtered with a nylon sieve size of $100 \mathrm{~m}$ was added to the buffer solution. Measurement of levels of $\mathrm{N}^{-\mathrm{NH}_{3}}$ rumen fluid was performed according to the instructions [20]. Determination of rumen fluid $\mathrm{pH}$ is done by inserting a portable $\mathrm{pH}$ meter on a sample of $50 \mathrm{ml}$ rumen fluid that has been filtered and placed in a glass beaker. Calibration is done by using a buffer of $\mathrm{pH} 6.82$ and $\mathrm{pH} 4$.

Methane gas content was measured by gas chromatography (Shimadzu Brands 2005, Type GC 2010 Detector FID (Flame Ionization Detector) which was calibrated with standard methane yield of $0.1 \%$. The $\mathrm{CH}_{4}$ gas measurement was performed following procedures developed by [11]. The substrate was incubated in rumen fluid in vitro tube at vacuum conditions. After observing the total gas volume, the gas produced was transferred into $10 \mathrm{ml}$ volume vacutainer vacuum at observation time of 12 hours and 24 hours after incubation. Then the gas was injected as much as $1 \mathrm{ml}$ into the inlet of Detector FID, the similar conditions to the standard conditions of $0.1 \%$ methane. The data obtained were in the form of methane content percentage in the total gas content. The implementation of $\mathrm{CH}_{4}$ measurement was performed in Integrated Research and Testing Laboratory (IRTL) at Gadjah Mada University.

Methane $(\%)=\frac{\text { (width of sample area) }}{\text { (width of standard area) }}$

The data were statistically analyzed by PASW STATISTICA 18 according to a randomized block design followed with a honesty significant difference test [21]. Standard errors were calculated from the residual mean square in the analysis of varians.

\section{Nutrient content}

\section{Results And Discussion}

Table 1. high CP content (> 18\%) at MOL and PFL potentially be used as a feed supplement in improving the quality of rations in ruminants. Use of MOL (as much as 10\%, 20\% and 30\%) and PFL (by 10\%) in the feed concentrate treatment resulted in increased protein levels ranging from $9.40 \%$ to $12.0 \%$. The increased use of concentrates of $30 \%, 40 \%$ to $50 \%$ in the feed $(\mathrm{P} 1=$ concentrates $30 \%: \mathrm{M} 70 \%$; $\mathrm{P} 2$ $=$ concentrates $40 \%: \mathrm{M} 60 \%$; and $\mathrm{P} 3=$ concentrates $50 \%: \mathrm{M} 50 \%)$ resulted in $\mathrm{CP}$ content feed increased. Feedstuffs protein sources are expensive, because its has a high digestibility due to the high content of $\mathrm{CP}$ and CF are low.

Results of preliminary in-vitro studies (Table 2.) on MOL and PFL potential as a protein supplements. Degradation value, the total gas production, microbial biomass, number of protozoa $\left(10^{4} \mathrm{sel} \mathrm{ml}^{-1}\right.$ rumen fluid), $\mathrm{NH}_{3}$ concentration at 4, 12 and 24 hours incubation at MOL significantly values $(\mathrm{P}<0.01)$ more high than PFL. The higher CT content of the PFL produces lower gas production.

Concentrate feed composed of MOL and PFL. The result of in-vitro, MOL more rapidly degraded in the rumen, therefore more available nitrogen as a source of amino acids for rumen microbial synthesis. PFL contains high tannin. The high tannin content of PFL was able to protect protein from excessive degradation processes in the rumen [11]. 
Table 1. The content of dry matter, organic matter, crude protein and crude fiber of feedstuffs and feed treatment

\begin{tabular}{|c|c|c|c|c|c|}
\hline \multicolumn{2}{|l|}{ Item } & DM (\%) & $\mathrm{OM}^{*}(\%)$ & $\mathrm{CP} *(\%)$ & $\mathrm{CF}^{*}(\%)$ \\
\hline \multicolumn{2}{|c|}{ Moringa oleifera leaves (MOL) } & 18.4 & 87.1 & 36.6 & 10.8 \\
\hline \multicolumn{2}{|c|}{ Paraserianthes falcataria leaves (PFL) } & 41.3 & 96.2 & 23.3 & 37.9 \\
\hline \multicolumn{2}{|c|}{ Coconut cake (CM) } & 86.7 & 92.1 & 21.8 & 13.3 \\
\hline \multicolumn{2}{|c|}{ Solid cassava waste $(\mathrm{O})$} & 46.7 & 98.5 & 3.34 & 11.6 \\
\hline \multicolumn{2}{|c|}{ Maize stover (M) } & 18.4 & 92.5 & 7.93 & 26.4 \\
\hline \multicolumn{6}{|c|}{ concentrate : maize stover $(\mathrm{M})$} \\
\hline \multirow{2}{*}{$\begin{array}{l}\text { AP1 } \\
\text { AP2 }\end{array}$} & $\mathrm{A} 30 \%: \mathrm{M} 70 \%$ & 91.1 & 92.2 & 9.41 & 20.0 \\
\hline & $\mathrm{A} 40 \%: \mathrm{M} 60 \%$ & 90.4 & 92.3 & 10.2 & 18.6 \\
\hline AP3 & $\mathrm{A} 50 \%: \mathrm{M} 50 \%$ & 89.9 & 92.9 & 10.7 & 17.2 \\
\hline & $\mathrm{B} 30 \%: \mathrm{M} 70 \%$ & 88.0 & 92.3 & 9.91 & 20.5 \\
\hline & $\mathrm{B} 40 \%: \mathrm{M} 60 \%$ & 87.8 & 93.1 & 10.8 & 19.3 \\
\hline BP3 & $\mathrm{B} 50 \%: \mathrm{M} 50 \%$ & 89.7 & 92.7 & 11.4 & 17.9 \\
\hline & $\mathrm{C} 30 \%: \mathrm{M} 70 \%$ & 90.4 & 92.0 & 9.91 & 20.8 \\
\hline & $\mathrm{C} 40 \%: \mathrm{M} 60 \%$ & 89.1 & 92.7 & 10.9 & 19.6 \\
\hline \multirow{2}{*}{$\begin{array}{l}\mathrm{CP} 3 \\
\mathrm{DP} 1\end{array}$} & $\mathrm{C} 50 \%: \mathrm{M} 50 \%$ & 89.9 & 92.4 & 11.6 & 18.4 \\
\hline & $\mathrm{D} 30 \%: \mathrm{M} 70 \%$ & 91.1 & 92.0 & 10.2 & 21.0 \\
\hline & $\mathrm{D} 40 \%: \mathrm{M} 60 \%$ & 90.8 & 92.1 & 11.0 & 19.9 \\
\hline \multicolumn{2}{|r|}{ D50\% : M50\% } & 90.3 & 92.1 & 12.1 & 18.8 \\
\hline \multicolumn{6}{|c|}{ 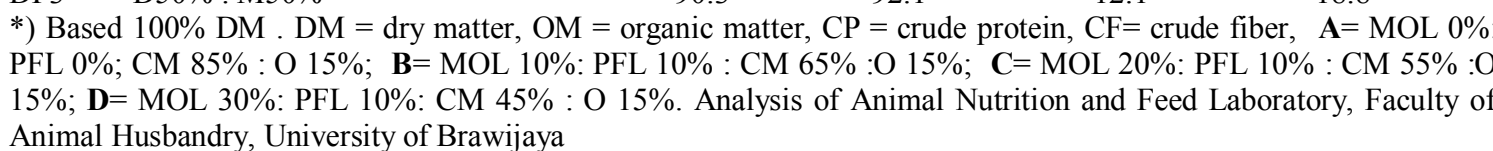 } \\
\hline
\end{tabular}

Table 2. Chemical composition and fermentation products in vitro from Moringa oleifera leaves and Paraserianthes falcataria leaves

\begin{tabular}{|c|c|c|}
\hline Variables & $\begin{array}{l}\text { Moringa oleifera } \\
\text { leaves }\end{array}$ & $\begin{array}{l}\text { Paraserianthes falcataria } \\
\text { leaves }\end{array}$ \\
\hline Dry matter $(\%)^{1}$ & 18.4 & 21,3 \\
\hline Organic matter $(\%)^{1}$ & 87.1 & 96.3 \\
\hline Crude protein $(\%)^{1}$ & 36.6 & 23.3 \\
\hline Crude fiber $(\%)^{1}$ & 10.8 & 37.9 \\
\hline Extract etter $(\%)^{1}$ & 5.79 & 5.41 \\
\hline Neutral Detergent Fiber $(\%)^{1}$ & 16.1 & 52.3 \\
\hline Acid Detergent Fiber (\%) ${ }^{1}$ & 12.7 & 43.1 \\
\hline Total phenol (TP) ${ }^{* 2}$ & 8.37 & 26.7 \\
\hline Total tannin $(\mathrm{TT})^{* 2}$ & 3.39 & 20.4 \\
\hline Condenzed tannin $(\mathrm{CT})^{* 2}$ & 0.19 & 5.89 \\
\hline Total saponin $(\mathrm{TS})^{* 2}$ & 5.89 & 3.98 \\
\hline Degradation of DM $(\%)^{3}$ & $68.3 \pm 1.81$ & $27.7 \pm 4.55$ \\
\hline Degradation of OM $(\%)^{3}$ & $76.8 \pm 2.30$ & $28.3 \pm 4.29$ \\
\hline Microbial biomass $(\mathrm{mg} / 0.5 \mathrm{gDM})^{3}$ & $114 \pm 8.75$ & $62.1 \pm 15.9$ \\
\hline Apparent digestibility $(\mathrm{mg} / 0.5 \mathrm{gDM})^{3}$ & $275 \pm 4.99$ & $119 \pm 6.27$ \\
\hline True digestibility $(\mathrm{mg} / 0.5 \mathrm{gDM})^{3}$ & $389 \pm 6.12$ & $180 \pm 9.30$ \\
\hline \multicolumn{3}{|c|}{ Number of protozoa $\left(10^{4} \text { cells } / \mathrm{ml} \text { rumen fluid }\right)^{3}$} \\
\hline Incubate 4 hours & $3.33 \pm 1.31$ & $2.93 \pm 0.87$ \\
\hline Incubate 12 hours & $2.93 \pm 1.06$ & $2.53 \pm 0.94$ \\
\hline Incubate 24 hours & $3.07 \pm 0.87$ & $2.93 \pm 0.63$ \\
\hline \multicolumn{3}{|l|}{$\mathrm{NH}_{3}(\mathrm{mg} / 100 \mathrm{ml} \text { rumen fluid })^{3)}$} \\
\hline Incubate 4 hours & $13.3 \pm 0.42$ & $8.23 \pm 0.19$ \\
\hline Incubate 12 hours & $13.4 \pm 0.37$ & $6.09 \pm 0.30$ \\
\hline Incubate 24 hours & $13.6 \pm 0.58$ & $8.32 \pm 0.31$ \\
\hline \multicolumn{3}{|l|}{$\mathrm{CH}_{4}(\% / \mathrm{ml})^{4)}$} \\
\hline Incubate 12 hours & 0.29 & 0.16 \\
\hline Incubate 24 hours & 0.57 & 0.35 \\
\hline \multicolumn{3}{|c|}{$\begin{array}{l}\text { 1) Based } 100 \% \text { DM, Analysis of Animal Nutrition and Feed Laboratory, Faculty of Animal Husbandry, University } \\
\text { of Brawijaya }\end{array}$} \\
\hline \multicolumn{3}{|c|}{ 2) Analyzed at the Laboratory Animal Research Center Ciawi. } \\
\hline \multicolumn{3}{|c|}{${ }^{3}$ ) Fermentation products in vitro incubation of 48 hours } \\
\hline \multicolumn{3}{|c|}{ 4) Analyzed at Integrated Research and Testing Laboratory (IRTL), Gadjah Mada University. } \\
\hline
\end{tabular}




\section{Fermentation products in vitro}

Feed treatment resulted in very significantly differences $(\mathrm{P}<0.01)$ to the value of $\mathrm{DM}$ and $\mathrm{OM}$ degradation (Table 3). DM degradation value and the value of feed OM degradation ranged from $64 \%-70 \%$.

Table 3. DM degradation value, OM degradation value, microbial biomass, apparent degradability and true degradability of feed treatment in vitro incubation of 48 hours

\begin{tabular}{|c|c|c|c|c|c|}
\hline Feed & $\begin{array}{l}\text { DM } \\
\text { degradation } \\
\text { value }\end{array}$ & $\begin{array}{l}\text { OM } \\
\text { degradation } \\
\text { value }\end{array}$ & $\begin{array}{l}\text { microbial } \\
\text { biomass }\end{array}$ & $\begin{array}{l}\text { Apparent } \\
\text { degradability }\end{array}$ & $\begin{array}{l}\text { True } \\
\text { degradability }\end{array}$ \\
\hline concentrate : maize stover(M) & $(\%)$ & $(\%)$ & $(\mathrm{mg} / 0.5 \mathrm{gDM})$ & $(\mathrm{mg} / 0.5 \mathrm{gDM})$ & $(\mathrm{mg} / 0.5 \mathrm{gDM})$ \\
\hline $\mathrm{AP} 1=\mathrm{A} 30 \%: \mathrm{M} 70 \%$ & $75.1^{\mathrm{d}} \pm 0.42$ & $78.4^{\mathrm{g}} \pm 1.34$ & $68.8^{\mathrm{d}} \pm 4.65$ & $284 \pm 4.59$ & $356^{\mathrm{f}} \pm 0.53$ \\
\hline $\mathrm{AP} 2=\mathrm{A} 40 \%: \mathrm{M} 60 \%$ & $72.9^{d} \pm 0.79$ & $76.3^{\text {efg }} \pm 0.53$ & $59.2^{\mathrm{bcd}} \pm 3.11$ & $290 \pm 0.80$ & $348^{\mathrm{e}} \pm 1.65$ \\
\hline $\mathrm{AP} 3=\mathrm{A} 50 \%: \mathrm{M} 50 \%$ & $72.9^{d} \pm 1.61$ & $76.7^{\mathrm{fg}} \pm 1.12$ & $60.7^{\text {bcd }} \pm 7.15$ & $304 \pm 13.67$ & $353^{\mathrm{f}} \pm 2.21$ \\
\hline $\mathrm{BP} 1=\mathrm{B} 30 \%: \mathrm{M} 70 \%$ & $66.6^{\mathrm{ab}} \pm 1.39$ & $70.5^{\mathrm{abc}} \pm 1.81$ & $57.9^{\mathrm{abcd}} \pm 2.87$ & $277 \pm 10.56$ & $330^{\mathrm{a}} \pm 1.81$ \\
\hline $\mathrm{BP} 2=\mathrm{B} 40 \%: \mathrm{M} 60 \%$ & $67.3^{\mathrm{ab}} \pm 0.75$ & $72.4^{\text {bcd }} \pm 1.32$ & $67.4^{\mathrm{cd}} \pm 0.47$ & $277 \pm 2.94$ & $343^{\mathrm{de}} \pm 0.90$ \\
\hline $\mathrm{BP} 3=\mathrm{B} 50 \%: \mathrm{M} 50 \%$ & $69.8^{c} \pm 2.08$ & $73.7^{\text {bcd }} \pm 2.39$ & $68.3^{\mathrm{cd}} \pm 3.29$ & $292 \pm 9.10$ & $355^{\mathrm{f}} \pm 1.18$ \\
\hline $\mathrm{CP} 1=\mathrm{C} 30 \%: \mathrm{M} 70 \%$ & $66.2^{\mathrm{a}} \pm 1.11$ & $71.4^{\mathrm{abcd}} \pm 1.59$ & $61.7^{\text {bcd }} \pm 3.55$ & $277 \pm 2.51$ & $339^{\text {cd }} \pm 0.89$ \\
\hline $\mathrm{CP} 2=\mathrm{C} 40 \%: \mathrm{M} 60 \%$ & $65.4^{\mathrm{a}} \pm 1.06$ & $68.4^{\mathrm{a}} \pm 1.33$ & $50.2^{\mathrm{ab}} \pm 3.71$ & $284 \pm 3.50$ & $334^{\mathrm{ab}} \pm 0.90$ \\
\hline $\mathrm{CP} 3=\mathrm{C} 50 \%: \mathrm{M} 50 \%$ & $69.4^{\mathrm{a}} \pm 1.08$ & $73.3^{\text {cde }} \pm 1.17$ & $57.9^{\text {abcd }} \pm 5.20$ & $288 \pm 4.34$ & $344^{\mathrm{de}} \pm 4.57$ \\
\hline $\mathrm{DP} 1=\mathrm{D} 30 \%: \mathrm{M} 70 \%$ & $64.7^{\mathrm{a}} \pm 1.52$ & $68.5^{\mathrm{a}} \pm 1.32$ & $55.5^{\mathrm{abc}} \pm 10.1$ & $288 \pm 2.15$ & $338^{\mathrm{bc}} \pm 1.95$ \\
\hline $\mathrm{DP} 2=\mathrm{D} 40 \%: \mathrm{M} 60 \%$ & $64.3^{a} \pm 0.76$ & $69.5^{\mathrm{ab}} \pm 1.65$ & $52.3^{\mathrm{ab}} \pm 6.51$ & $289 \pm 0.92$ & $346^{\mathrm{e}} \pm 0.47$ \\
\hline $\mathrm{DP} 3=\mathrm{D} 50 \%: \mathrm{M} 50 \%$ & $66.4^{\mathrm{a}} \pm 0.45$ & $70.4^{\mathrm{abc}} \pm 1.03$ & $46.0^{\mathrm{a}} \pm 1.68$ & $298 \pm 1.57$ & $343^{\mathrm{e}} \pm 1.85 \mathrm{~d}$ \\
\hline A & $73.7^{c} \pm 3.74$ & $77.2^{b} \pm 3.28$ & $62.9^{b c} \pm 15.5$ & $293^{\mathrm{b}} \pm 30.7$ & $353^{\mathrm{c}} \pm 12.4$ \\
\hline $\mathrm{B}$ & $67.7^{\mathrm{b}} \pm 5.08$ & $72.2^{\mathrm{a}} \pm 4.98$ & $64.6^{c} \pm 17.3$ & $282^{a} \pm 25.9$ & $343^{b} \pm 37.1$ \\
\hline $\mathrm{C}$ & $66.9^{b} \pm 6.37$ & $71.0^{\mathrm{a}} \pm 7.36$ & $56.6^{\mathrm{ab}} \pm 17.6$ & $283^{a} \pm 16.6$ & $339^{a} \pm 15.3$ \\
\hline $\mathrm{D}$ & $65.1^{\mathrm{a}} \pm 3.25$ & $69.5^{\mathrm{a}} \pm 2.83$ & $51.3^{\mathrm{a}} \pm 14.6$ & $292^{\mathrm{b}} \pm 15.6$ & $342^{\mathrm{b}} \pm 12.4$ \\
\hline P1 & $68.2^{\mathrm{ab}} \pm 14.1$ & $72.2^{\mathrm{ab}} \pm 12.9$ & $61.0^{\mathrm{a}} \pm 17.4$ & $282^{a} \pm 16.5$ & $341^{\mathrm{a}} \pm 32.7$ \\
\hline $\mathrm{P} 2$ & $67.4^{\mathrm{a}} \pm 11.5$ & $71.7^{a} \pm 10.6$ & $57.3^{\mathrm{a}} \pm 23.4$ & $285^{\mathrm{a}} \pm 18.1$ & $343^{a} \pm 19.1$ \\
\hline P3 & $69.6^{\mathrm{b}} \pm 8.14$ & $73.5^{b} \pm 7.77$ & $58.2^{\mathrm{a}} \pm 27.7$ & $296^{\mathrm{b}} \pm 20.9$ & $349^{b} \pm 18.9$ \\
\hline
\end{tabular}

Based 100\% DM, Analysis of Animal Nutrition and Feed Laboratory, Faculty of Animal Husbandry, University of Brawijaya ${ }^{\mathrm{a}-\mathrm{e}}$ : Different superscripts in the same column showed very significantly differences $(\mathrm{P}<0.01) .{ }^{\mathrm{a}}$ The same superscript in the same column indicates no significant difference $(\mathrm{P}>0.05)$.

The feed with MOL and PFL produce DM and OM degradation value is lower than the feed without MOL and PFL (AP1, AP2 and AP3). Feed without MOL and PFL is more easily degraded by rumen microbes. $\mathrm{DM}$ and $\mathrm{OM}$ degradation is used as an indicator to determine feed quality due to degradation of the value indicates the amount of nutrients in feedstuffs that can be utilized by rumen microbes and animals. Feed DP3 (D50\%: M50\%) resulted in a lower degradation rate, because the feed DP3 difficult to degrade due to the presence of tannins in the leaves. Feed quality protein sources can be protected by the tannins of rumen microorganisms degradation in neutral $\mathrm{pH}$ conditions, which is expected to be available at post-ruminal digestive tract. Low $\mathrm{pH}$ conditions in the abomasum causing bond tannin-protein complex can be separated and the protein can be digested by the enzyme pepsin that amino acids available to the animal.

Production of microbial biomass indicates the number of rumen microbes (bacteria, protozoa, fungi) that play a role in degrading the feed in the rumen. DP3 feed produces the lowest microbial biomass production. CT compounds and saponins from MOL and PFL in feed resulted DP3 protease and cellulase enzyme activity inhibited rumen microbes, which marked the production of microbial biomass and low feed degradation. Production of microbial biomass and high digestibility true value on feed AP1, BP2 and BP3 show potential feed readily soluble and easily degraded in the rumen.

$\mathrm{NH}_{3}$ concentration ranged from 6.99 to $11.7 \mathrm{mg} / 100 \mathrm{ml}$ rumen fluid allows for optimal microbial growth. $\mathrm{NH}_{3}$ levels for optimal microbial growth that ranged from a minimum of $5-8 \mathrm{mg} / 100 \mathrm{ml}$ rumen fluid. $\mathrm{NH}_{3}$ is one result of an overhaul of protein by rumen microbes. 24-hour in vitro incubation accumulation reshuffle results so that the rumen microbial protein by $\mathrm{NH}_{3}$ concentration is higher than the 12-hour incubation. Feed DP3 produce high $\mathrm{NH}_{3}$ concentration at 24 hours incubation. This case shows the proportion of $50 \%$ forage: $50 \%$ concentrate on feed D produces optimal microbial growth. The secondary compounds in MOL and PFL on Feed DP3, causing feed more protected from microbial degradation processes in the rumen, so that the value of DM degradation and degradation OM are low (Table 3). 
Table 4. $\mathrm{NH}_{3}$ concentration, ratio $\left(\mathrm{C}_{2}+\mathrm{C}_{4}\right) / \mathrm{C}_{3}$ of feed at 4,12 and 24 hours incubation

\begin{tabular}{|c|c|c|c|c|c|c|}
\hline \multirow{2}{*}{$\begin{array}{l}\text { Feed } \\
\text { concentrate : maize stover(M) }\end{array}$} & \multicolumn{3}{|c|}{$\mathrm{NH}_{3}(\mathrm{mg} / 100 \mathrm{ml}$ rumen fluid) } & \multicolumn{3}{|c|}{ Ratio $\left(\mathrm{C}_{2}+\mathrm{C}_{4}\right) / \mathrm{C}_{3}$} \\
\hline & 4 hours & 12 hours & 24 hours & 4 hours & 12 hours & 24 hours \\
\hline $\mathrm{AP} 1=\mathrm{A} 30 \%: \mathrm{M} 70 \%$ & $9.26 \pm 2.98$ & $11.7^{\mathrm{b}} \pm 0.70$ & $9.89 \pm 0.60$ & 4.58 & 3.28 & 2.99 \\
\hline $\mathrm{AP} 2=\mathrm{A} 40 \%: \mathrm{M} 60 \%$ & $8.75 \pm 3.72$ & $8.90^{\mathrm{a}} \pm 3.10$ & $10.6 \pm 1.11$ & 5.13 & 3.03 & 2.99 \\
\hline $\mathrm{AP} 3=\mathrm{A} 50 \%: \mathrm{M} 50 \%$ & $8.83 \pm 3.27$ & $8.59^{a} \pm 2.62$ & $8.53 \pm 0.79$ & 4.73 & 2.91 & 2.65 \\
\hline $\mathrm{BP} 1=\mathrm{B} 30 \%: \mathrm{M} 70 \%$ & $7.78 \pm 2.00$ & $8.22^{a} \pm 1.96$ & $9.46 \pm 0.20$ & 5.01 & 3.23 & 3.13 \\
\hline $\mathrm{BP} 2=\mathrm{B} 40 \%: \mathrm{M} 60 \%$ & $8.12 \pm 1.40$ & $9.22^{\mathrm{a}} \pm 2.14$ & $9.44 \pm 0.53$ & 5.04 & 3.28 & 3.11 \\
\hline $\mathrm{BP} 3=\mathrm{B} 50 \%: \mathrm{M} 50 \%$ & $7.48 \pm 1.71$ & $8.14^{\mathrm{a}} \pm 3.19$ & $10.3 \pm 2.19$ & 4.97 & 3.58 & 3.03 \\
\hline $\mathrm{CP} 1=\mathrm{C} 30 \%: \mathrm{M} 70 \%$ & $8.76 \pm 3.60$ & $8.92^{\mathrm{a}} \pm 3.19$ & $8.75 \pm 2.73$ & 4.97 & 3.46 & 3.29 \\
\hline $\mathrm{CP} 2=\mathrm{C} 40 \%: \mathrm{M} 60 \%$ & $8.16 \pm 1.63$ & $8.29^{\mathrm{a}} \pm 2.61$ & $8.71 \pm 2.68$ & 4.64 & 3.59 & 2.95 \\
\hline $\mathrm{CP} 3=\mathrm{C} 50 \%: \mathrm{M} 50 \%$ & $7.90 \pm 1.05$ & $9.20^{\mathrm{a}} \pm 1.99$ & $8.61 \pm 1.75$ & 4.63 & 3.56 & 3.56 \\
\hline $\mathrm{DP} 1=\mathrm{D} 30 \%: \mathrm{M} 70 \%$ & $7.17 \pm 2.21$ & $6.99^{\mathrm{a}} \pm 0.80$ & $8.48 \pm 1.85$ & 4.58 & 3.52 & 3.08 \\
\hline $\mathrm{DP} 2=\mathrm{D} 40 \%: \mathrm{M} 60 \%$ & $8.04 \pm 2.10$ & $8.65^{\mathrm{a}} \pm 2.34$ & $8.08 \pm 1.54$ & 4.81 & 3.58 & 3.24 \\
\hline $\mathrm{DP} 3=\mathrm{D} 50 \%: \mathrm{M} 50 \%$ & $7.48 \pm 1.71$ & $8.29^{\mathrm{a}} \pm 2.61$ & $8.10 \pm 1.09$ & 4.66 & 3.54 & 2.88 \\
\hline $\mathrm{A}$ & $8.94 \pm 0.82$ & $9.72^{b} \pm 5.07$ & $9.67 \pm 3.15$ & 4.80 & 3.07 & 2.88 \\
\hline B & $7.79 \pm 0.96$ & $8.53^{\mathrm{ab}} \pm 1.80$ & $9.72 \pm 1.40$ & 5.01 & 3.35 & 3.09 \\
\hline $\mathrm{C}$ & $8.27 \pm 1.34$ & $8.80^{\mathrm{ab}} \pm 1.39$ & $8.69 \pm 0.20$ & 4.73 & 3.54 & 3.27 \\
\hline $\mathrm{D}$ & $7.56 \pm 1.32$ & $7.98^{\mathrm{a}} \pm 2.62$ & $8.22 \pm 0.67$ & 4.68 & 3.54 & 3.06 \\
\hline P1 & $8.24 \pm 2.83$ & $8.95 \pm 5.94$ & $9.14 \pm 1.94$ & 4.78 & 3.37 & 3.12 \\
\hline P2 & $8.27 \pm 0.97$ & $8.76 \pm 1.17$ & $9.21 \pm 3.24$ & 4.89 & 3.36 & 3.06 \\
\hline P3 & $7.92 \pm 1.91$ & $8.56 \pm 1.40$ & $8.88 \pm 2.84$ & 4.74 & 3.37 & 3.02 \\
\hline
\end{tabular}

${ }^{\mathrm{a}-\mathrm{b}}$ : Different superscripts in the same column showed very significantly differences $(\mathrm{P}<0.01) .{ }^{\mathrm{a}}$ The same superscript in the same column indicates no significant difference $(\mathrm{P}>0.05)$.

Fermentation of feed with higher results of acetic acid $\left(\mathrm{C}_{2}\right)$ and butyric acid $\left(\mathrm{C}_{4}\right)$, produce more greater ratio $\left(\mathrm{C}_{2}+\mathrm{C}_{4}\right) / \mathrm{C}_{3}$. Data Feed DP3 in Table 4, shows the proportion of $\mathrm{C}_{3}$ increased compared the other feed, so that the value of the ratio $\left(\mathrm{C}_{2}+\mathrm{C}_{4}\right) / \mathrm{C}_{3}$ is lower. Variation of VFA production $\left(\mathrm{C}_{2}, \mathrm{C}_{3}, \mathrm{C}_{4}\right)$ causes differences in $\mathrm{CH}_{4}$ production in the rumen [2]. $\mathrm{C}_{2}$ and $\mathrm{C}_{4}$ play a role in the formation of $\mathrm{CH}_{4}$, when there is competition with the formation of $\mathrm{H}$ ions using propionate $\left(\mathrm{C}_{3}\right)$ in the rumen. Increased ratio $\left(\mathrm{C}_{2}+\mathrm{C}_{4}\right) / \mathrm{C}_{3}$ will produce high availability $\mathrm{C}_{2}$ and $\mathrm{C}_{4}$ so that the higher the production of $\mathrm{CH}_{4} \cdot \mathrm{C}_{2}$ and $\mathrm{C}_{4}$ are the source of energy for oxidation. $\mathrm{C}_{2}$ is a non glukogenik compounds, and almost all tissues of the body are able to oxidize. Oxidation process produces high heat increament so that the lower feed efficiency. $\mathrm{C}_{3}$ is a sugar compound precursors or primary glukogenik. $\mathrm{C}_{3}$ of the reticulo-rumen is absorbed into the blood, through the portal vein to the liver to be converted into glucose through gluconeogenesis.

\section{Methane production in vitro}

Feed AP3 produce the highest gas production at 48 hours incubation in the amount of $90.8 \mathrm{ml} /$ $0.5 \mathrm{gDM}$. Feed AP3 without MOL and PFL easily degraded so that the resulting high gas production. Feed DP3 produces gas production, degradation of DM and OM were lower (Table 2.). Gas production depends on the amount of substrate degraded [22]. Feed DP3 able to produce $\mathrm{CH}_{4}$ gas production $34 \%$ lower than the feed treatment without MOL and PFL. Feed without MOL and PFL produce CH4 gas production averaging $1.25 \%$, while feed DP3 produce $\mathrm{CH} 4$ gas production of $0.76 \%$. Low $\mathrm{CH}_{4}$ production on feed $\mathrm{DP}_{3}$, predictable result to supplementation MOL 30\% and PFL10\%. PFL leaves fermentation at 24 hours of incubation proved to produce $\mathrm{CH}_{4}$ gas production amounted to $0.35 \%$, while MOL fermentation, $\mathrm{CH}_{4}$ production yield of $0.57 \%$ (Table 5.).

Supplementation of feed use MOL $30 \%$ and PFL $10 \%$, causing a low $\mathrm{CH}_{4}$ production. Ruminant feed is expected to increase production because it produces less energy in the form of $\mathrm{CH} 4$ is lost from the body. MOL-based feed supplements provide a positive response because it has a balanced content of essential amino acids [13]. This research results are consistent with previous research on Moringa oleifera (30\%) and Samanea saman $(10 \%)$ leaves supplementation. Supplementation of Moringa oleifera $(30 \%)$ and Samanea saman $(10 \%)$ leaves in the concentrate feed ( $18 \%$ crude protein) is given by $1.0 \% \mathrm{BW}$ on basal diet of maize stover produce average daily gain of $87.7 \pm 18.3 \mathrm{~g} / \mathrm{head} /$ day and normal range blood profile of growing rams. [23] 
Table 5. Total gas production $(\mathrm{ml} / 0.5 \mathrm{gDM})$, gas $\mathrm{CH}_{4}(\mathrm{ml} / 0.5 \mathrm{gDM})$ of feed treatment in vitro at 12 and $24 \mathrm{~h}$ incubation

\begin{tabular}{|c|c|c|c|c|c|c|}
\hline \multirow{2}{*}{$\begin{array}{l}\text { Feed } \\
\text { concentrate : maize stover(M) }\end{array}$} & \multicolumn{2}{|c|}{$\begin{array}{c}\text { Total volume of gas }{ }^{1}(\mathrm{ml} / \\
0.5 \mathrm{~g} \text { DM })\end{array}$} & \multicolumn{2}{|c|}{$\begin{array}{c}\text { concentration } \mathrm{CH}_{4}{ }^{*} \\
(\% / \mathrm{ml})\end{array}$} & \multicolumn{2}{|c|}{$\begin{array}{l}\text { Volume } \mathrm{CH}_{4}^{* *} \\
(\mathrm{ml} / 0.5 \mathrm{~g} \mathrm{DM})\end{array}$} \\
\hline & 12 hours & 24 hours & 12 hours & 24 hours & 12 hours & 24 hours \\
\hline $\mathrm{AP} 1=\mathrm{A} 30 \%: \mathrm{M} 70 \%$ & 52.9 & 86.5 & 0.60 & 1.27 & 0.32 & 1.10 \\
\hline $\mathrm{AP} 2=\mathrm{A} 40 \%: \mathrm{M} 60 \%$ & 57.8 & 90.8 & 0.55 & 1.24 & 0.32 & 1.13 \\
\hline $\mathrm{AP} 3=\mathrm{A} 50 \%: \mathrm{M} 50 \%$ & 57.1 & 90.7 & 0.58 & 1.24 & 0.33 & 1.12 \\
\hline $\mathrm{BP} 1=\mathrm{B} 30 \%: \mathrm{M} 70 \%$ & 51.8 & 84.2 & 0.41 & 1.02 & 0.21 & 0.86 \\
\hline $\mathrm{BP} 2=\mathrm{B} 40 \%: \mathrm{M} 60 \%$ & 53.9 & 86.3 & 0.51 & 0.90 & 0.27 & 0.78 \\
\hline $\mathrm{BP} 3=\mathrm{B} 50 \%: \mathrm{M} 50 \%$ & 54.7 & 85.4 & 0.38 & 0.95 & 0.21 & 0.81 \\
\hline $\mathrm{CP} 1=\mathrm{C} 30 \%: \mathrm{M} 70 \%$ & 45.8 & 76.5 & 0.49 & 0.87 & 0.22 & 0.67 \\
\hline $\mathrm{CP} 2=\mathrm{C} 40 \%: \mathrm{M} 60 \%$ & 45.8 & 74.0 & 0.48 & 0.82 & 0.22 & 0.61 \\
\hline $\mathrm{CP} 3=\mathrm{C} 50 \%: \mathrm{M} 50 \%$ & 48.1 & 78.0 & 0.47 & 0.79 & 0.23 & 0.62 \\
\hline $\mathrm{DP} 1=\mathrm{D} 30 \%: \mathrm{M} 70 \%$ & 35.1 & 61.8 & 0.57 & 0.91 & 0.20 & 0.56 \\
\hline $\mathrm{DP} 2=\mathrm{D} 40 \%: \mathrm{M} 60 \%$ & 44.0 & 73.8 & 0.52 & 0.86 & 0.23 & 0.63 \\
\hline $\mathrm{DP} 3=\mathrm{D} 50 \%: \mathrm{M} 50 \%$ & 41.9 & 71.8 & 0.47 & 0.76 & 0.20 & 0.55 \\
\hline A & 55.9 & 89.3 & 0.58 & 1.25 & 0.32 & 1.12 \\
\hline B & 53.4 & 85.3 & 0.43 & 0.96 & 0.23 & 0.82 \\
\hline $\mathrm{C}$ & 46.6 & 76.2 & 0.48 & 0.83 & 0.22 & 0.63 \\
\hline $\mathrm{D}$ & 40.3 & 69.1 & 0.52 & 0.84 & 0.21 & 0.58 \\
\hline P1 & 46.4 & 77.3 & 0.52 & 1.02 & 0.24 & 0.80 \\
\hline $\mathrm{P} 2$ & 50.4 & 81.2 & 0.52 & 0.96 & 0.26 & 0.79 \\
\hline P3 & 50.4 & 81.5 & 0.48 & 0.94 & 0.24 & 0.77 \\
\hline
\end{tabular}

Specification: ${ }^{1}$ Gas production through syiring, * Analysis of $\mathrm{CH}_{4}$ at Integrated Research and Testing Laboratory (IRTL), Gadjah Mada University., ** volume $\mathrm{CH}_{4}=$ total volume of gas ${ }^{1} \mathrm{x}$ concentration $\mathrm{CH}_{4}{ }^{*}$

\section{Conclusion}

It can be concluded that the usage of concentrate feed (MOL 30\% : PFL 10\% : coconut cake $45 \%$ : solid cassava waste $15 \%$ ) with the proportion of concentrate $50 \%$ : forage $50 \%$ was be able to produce normal fermentation process and low $\mathrm{CH}_{4}$ production. Indicator of normal fermentation at 48 hours of incubation in-vitro indicated DM degradation value $66.36 \%$, OM degradation value $70.41 \%$, gas production $94.83 \mathrm{ml}$, microbial biomass $46 \mathrm{mg}, \mathrm{pH} 6.67, \mathrm{NH}_{3}$ concentration 7.48 until $8.29 \mathrm{mg} / 100 \mathrm{ml}$ rumen fluid and proportion VFA $\left.\left(\mathrm{C}_{2}: \mathrm{C}_{3}: \mathrm{C}_{4}=65: 26: 9\right)\right)$ and the lowest $\mathrm{CH}_{4}$ gas production $(<1 \%$ 24-hour incubation). It is suggested that in the future studies are in-vivo testing of the usage of MOL 30\%: PFL 10\% in the concentrate feed.

\section{Acknowledgements}

This study was funded by Directorate General of Higher Education, Ministry of Education and Culture the Republic of Indonesia and partly supported by Tribhuwana Tunggadewi University fund. Many thanks are due to official staff of Animal Nutrition Laboratory, Faculty of Animal Husbandry for their valuable assistance and supports.

\section{References}

[1] M.F. Iqbal, Y. Fen Cheng, W. Yun Zhu and B. Zeshan, Mitigation of ruminant methane production: current strategies, constraints and future options. Word J. microbiotechnol 24, 2008, pp.2747-2755.

[2] Z.A. Gworgwor, T.F. Mbahi and B. Yakubu, Environmental implications of methane production by ruminants: A Review. Journal of Sustainable in Agriculture and Environment. Vol 2(1). 2006, ISSN 0794-8867 Retrieved Mei 9, 2013, From https://docs.google.com/file/d/0B4eGGuLlL3UeYmZvSjJpdFVmbGc/edit?usp=sharing

[3] P.R. Cheeke, Actual and potential applications of Yucca schidigera and Quillaja saponaria saponins in human and animal nutrition. In Proceedings of the American Society of Animal Science, Indiapolis 2000 10p. Retrieved March 9, 2011, from http://www.asas. org/JAS/symposia/proceeding/0909.pd

[4] C.S. Mc Sweeney, B. Palmer, D.M. Mc Neill and D.O Krause, Microbial interactions with tannins: nutritional consequences for ruminants. Anim. Feed Sci. and Technol. 91, 2001, pp.83-93. Retrieved Mei 21, 2011, from http://espace.library.uq.edu.au/view/UQ:60404

[5] R.J. Wallace, N.R. Mc Ewen, F.M. McIntosh, B. Teferedegne and C.J. Newbold, Natural products as manipulators of rumen fermentation. Asian-Aust. J. Anim. Sci. 15, 2002, pp.1458-1468.

[6] H.P.S. Makkar, Quantification of tannin in the tree and shrub legumes: A Laboratory Manual. Kluwer Academic Publishers, Dorrecht, The Netherlands, 2003.

[7] R.A. Leng, Tree foliage in ruminant nutrition. FAO Animal Production and Health Paper No 139. Rome, 1997 pp 100 Retrieved August 52011 from http://www.fao.org/docrep/003/w7448e/W7448E00.htm

[8] J.Y. Takahashi, Y. Miyagawa, Kojima and Umetsu, Effect of Yucca schidigera extract, probiotics, momensin and L-cysteine on rumen methanogenesis. Asian-Australian. J. Anim Sci. 13, 2000, pp.499-501, 
[9] B. Santoso, Rumen fermentation characteristic and methanogenesis in sheep fed silage based diet supplemented with Yucca schidigera or Yucca schidigera combined with nisin. Bulletin of. Animal Science 28, 2005, pp.13-18.

[10] B. Santoso, B. Mwenya, C. Sar and J. Takahashi, CH4 production and energy partitioning in sheep fed basal silage or hay grass Timothy. Jurnal Ilmu Ternak dan Veteriner (JITV), Volume 12 No. 1 (2007): 27-33. (in Indonesian) Retrieved July 15, 2013, from http://peternakan.litbang.deptan.go.id/?q=node/361.

[11] B. Santoso, and B. Tj. Hariadi. Effect of supplementation of Acacia mangium will on Pennisetum purpureum to the fermentation characteristics and methane production in vitro. Jurnal Media Peternakan. Agustus Vol 30 No. 2, 2007. pp.106-113. (in Indonesian) Retrieved May 7, 2009, from journal.ipb.ac.id/index.php/mediapeternakan/article/download/987/269

[12] A. Jayanegara, G. Goel, H.P.S. Makkar, and K. Becker, Reduction in methane emissions from ruminants by plant secondary metabolites: Effects of Polyphenols and Saponins. In: Odongo N E, Garcia M and Viljoen G J (eds), Sustainable Improvement of Animal Production and Health. Food and Agriculture Organization of the United Nations, Rome, 2010 pp. 151-157, Retrieved August 11, 2011, from anuragaja.staff.ipb.ac.id/.../Jayanegara 2010 SIAPH-FAO tannin-saponin-CH4.pdf-

[13] H.P.S. Makkar, and K. Becker, Nutrional value and antinutritional components of whole and ethanol extracted Moringa oleifera leaves. Animal Feed Science and Technology, Volume 63, Issues 1-4, 1 December 1996, pp.211-228 Retrieved June 12, 2012, from http://www.sciencedirect.com/science/article/pii/S0377840196010231

[14] H. Soetanto, E. Marhaeniyanto and S. Chuzaemi, Implementation technology supplementation based leaf Moringa oleifera and mollases on goat farmers. J. Buana Sains Vol. 11 No 1, June 2011. pp.25-34. (in Indonesian) Retrieved June 122012 from library.unitri.ac.id/index.php? $\mathrm{p}=$ show detail\&id $=177$

[15] H. Soetanto and Firsoni, Effect of supplementation with molasses block containing gliricidia or moringa leaves on in-vitro gas production and microbial protein synthesis. Word Conference on Animal Production. Cape Town. South Africa. 24-28 Nop. 2008.

[16] J.K. Murro. V.R.M. Muhikambele, and S.V. Sarwatt, Moringa oleifera leaf meal can replace cottonseed cake in the concentrate mix fed with Rhodes Grass (Chloris gayana) hay for growing sheep. Livestock Research for Rural Development Vol. 15 (11), 2003.

[17] AOAC (Association Of Official Analytical Chemists), Official methods of analysis of the association of analytical chemist. $16^{\text {th }}$ ed. Association of Official Analitical Chemist, Arlington, VA. USA, 1990.

[18] P.J.Van Soest, J.B. Robertson, B.A.Lewis, Methods for fiber, neutral detergent fiber, and non-starch polysaccharides in relation to animal nutrition. J. Dairy Sci. 74, 1991, pp. 3583-3597.

[19] H.P.S. Makkar, M. Blủmmel and K. Becker. Application of an in-vitro gas method to understand the effect of natural plant products on availability and partitioning of nutrients. Institute for Animal Production in the Tropics and Subtropic, Univ. of Stutgarat, Germany, 1997.

[20] E.J. Conway, Microdiffusion analysis and volumetric error. Crosby cockwood, London, UK, 1957.

[21] S. Yitnosumartono, Experiment, design, analysis and interpretation. Gramedia. Jakarta, 1993. (in Indonesian)

[22] H.P.S. Makkar, M. Blủmmel and K. Becker, Formation of complexes between polyvinyl pyrrolidone or polyethylene glycol and tannins and their implication in gas production and true digestibility in in-vitro techniques. British Journal of Nutrition 73 , 1995 pp. 897-913.

[23] E. Marhaeniyanto, H. Soetanto, Kusmartono and Hartutik, Blood profile and daily gain of fat-tailed growing rams receiving tree foliages to substitute other ingredients in the concentrate diets. IOSR Journal of Agriculture and Veterinary Science (IOSR-JAVS) e-ISSN: 2319-2380, p-ISSN: 2319-2372. Volume 3, Issue 6 (Jul. - Aug. 2013), PP 23-27. Retrieved July 18, 2013, from http://www.iosrjournals.org/iosr-javs/papers/vol3-issue6/E0362327.pdf 